\title{
Pemetaan Standard Operating Procedure Penerimaan, Pemuatan, Pembongkaran, dan Pengeluaran Peti Kemas
}

\author{
Somadi \\ Program Studi D4 Logistik Bisnis, Politeknik Pos Indonesia \\ email: somadi@poltekpos.ac.id
}

\begin{abstract}
ABSTRAK
Waktu proses pemasukan, pemuatan, pembongkaran dan pengeluaran petikemas di Terminal Petikemas Surabaya yang dikelola oleh PT. Terminal Petikemas Surabaya hingga kini masih dirasa cukup lama oleh para pengguna terminal. Keterlambatan waktu tersebut salah satunya disebabkan karena pengguna terminal seringkali mengalami kebingungan dalam menerapkan SOP (standard operating procedure) layanan yang ada di dalam terminal. Tujuan penelitian untuk mengetahui SOP pemasukan, pemuatan, pembongkaran dan pengeluaran petikemas di PT. Terminal Petikemas Surabaya. Untuk memecahkan permasalahan dalam penelitian ini menggunakan analisis deskriptif. Berdasarkan hasil penelitian bahwa SOP penerimaan petikemas dimulai dari pengiriman data COPARN, pembuatan job order, pencetakan dan distribusi E-CEIR, proses pemindahan petikemas dari truk ke lapangan penumpukan, hingga kendaraan meninggalkan terminal. Sementara itu, SOP pemuatan petikemas dimulai dari pengiriman, penerimaan dan pemeriksaan dokumen, pemindahan petikemas dari lapangan penumpukan ke truk untuk dimuat ke kapal, hingga konfirmasi muatan dan keberangkatan kapal. Untuk SOP pembongkaran petikemas dimulai dari persiapan pembongkaran, menginput data ke dalam sistem, pembongkaran petikemas dari kapal ke atas truk, pemeriksaan, mengangkut petikemas dari dermaga ke lapangan penumpukan, hingga pemindahkan petikemas dari truk ke lapangan penumpukan. Sedangkan, SOP pengeluaran petikemas dimulai pengiriman delivery order online, pembuatan job order pengeluaran petikemas, pemrosesan job order pengeluaran petikemas, hingga pengecekan antara data fisik dan sistem.
\end{abstract}

Kata Kunci: $\quad$ Pemetaan SOP Petikemas, Pemasukan Petikemas, Pemuatan Petikemas, Pembongkaran Petikemas, Pengeluaran Petikemas

\section{PENDAHULUAN}

Perkembangan terminal petikemas saat ini terus memperlihatkan eksistensinya dengan seiring meningkatnya aktivitas ekpor dan impor. Sehingga keberadaan terminal petikemas sangat dibutuhkan dalam mendukung perdagangan baik secara nasional maupun internasional. Untuk itu pengelolaan terminal petikemas perlu terus dilakukan perbaikan guna menjaga kepuasan penggunanya.

Terminal petikemas diartikan sebagai wilayah atau tempat tertentu di daratan dengan batas-batas yang jelas dan merupakan tempat pertemuan antara angkutan laut dan angkutan darat yang menganut sistem unitisasi, serta dilengkapi dengan prasarana dan sarana angkutan barang untuk tujuan ekspor dan impor dengan cara pengemasan khusus, sehingga dapat berfungsi sebagai pelabuhan (Wahono, 2015). Supriyono (2010) dalam Wahono (2015), adapun fungsi terminal petikemas yaitu tempat pemuatan dan pembongkaran petikemas dari kapal-truk atau sebaliknya, pengepakan dan pembongkaran petikemas (CFS), pengawasan dan penjagaan petikemas beserta muatannya, penerimaan armada kapal, dan pelayanan cargo handling Petikemas dan lapangan penumpukannya. Menurut Triatmodjo (2009) dalam Wahono (2015), terminal petikemas memiliki fasilitas antara lain berupa dermaga, apron, container yard, CFS (container freight station), menara pengawas, bengkel pemeliharaan dan fasilitas lain seperti jalan masuk, gedung perkantoran, tempat parkir, dan lainnya .

Dalam operasionalnya, terminal petikemas yang ada di Indonesia menghadapi permasalahan yang harus segera dilakukan perbaikan. Berdasarkan penelitian Bastyan (2017) di Terminal Petikemas Surabaya, bahwa seluruh dimensi kualitas layanan menghasilkan tingkat kepuasan "cukup puas" yang artinya bahwa pelanggan menilai pelayanan yang diberikan PT. TPS sudah cukup memenuhi harapan namun masih belum maksimal. Senada dengan dengan penelitian dari Amanullah et al., (2018), bahwa layanan dan utilitas pada terminal petikemas Pelabuhan Panjang dikategorikan cukup baik namun arus kapal dan petikemas mengalami penurunan, hal ini kemungkinan beralihnya kapal-kapal ke terminal petikemas lain yang memiliki fasilitas lebih baik dibanding Terminal PetiKemas Pelabuhan Panjang, selain dari permasalahan ekonomi global. 
Sementara itu, hasil penelitian dari Handajani (2004), bahwa secara keseluruhan kelancaran operasi di terminal petikemas sangat bergantung pada pelayanan chassis truck di container yard berupa pengaturan pola penumpukan petikemas di container yard maupun penggunaan rubber tyred gantry secara optimal. Sehingga dapat direkomendasikan beberapa hal yaitu pengaturan penumpukan petikemas di container yard sesuai dengan urutan berat dan tujuan, penambahan jumlah chassis truck sehingga kondisi pelayanan lebih optimal, dan perlunya keberadaan seorang pengawas yang mengatur antrian chassis truck di gantry crane maupun di container yard. Sedangkan hasil penelitian dari Khusyairi \& Hisyam (2016), bahwa kinerja pelayanan operasional petikemas dipelabuhan Pangkalbalam kota Pangkalpinang dikategorikan baik. Hal ini terlihat pada nilai $B O R, Y O R, B T P, K D$ dan kinerja peralatan bongkar muat dimana nilai-nilainya memenuhi kriteria yang ditetapkan oleh Direktorat Jenderal Perhubungan Laut. Namun kondisi pelabuhan saat ini masih terlihat berantakan, dan kinerja peralatan pelayanan petikemas seperti forklift, mobile crane, dan fix jib crane dinilai baik, tetapi untuk head truck dan chassis dinilai kurang baik.

PT. Terminal Petikemas Surabaya (TPS) berlokasi di Pelabuhan Tanjung Perak. TPS berdekatan dengan jalan Raya Tol Surabaya dan jalur Kereta Api. Pelayanan yang diberikan oleh pengelola TPS selama 24 jam. Fasilitas yang tersedia di TPS antara lain dermaga internasional, dermaga domestik, lapangan penumpukan internasional, lapangan penumpukan petikemas reefer, dan railway (2 track), lapangan penumpukan domestik, area pemeriksaan bea cukai. Lapangan penumpukan internasional dengan luas 35 hektar dengan kapasitas 32.223 TEUS, sedangkan penumpukan petikemas reefer memiliki kapasitas ekspor 350 TEUS, dan impor 882 TEUS, dan reefer plug sebanyak 909 plugging. Sementara itu railway yang dimiliki sepanjang 420 meter. Untuk lapangan penumpukan domestik memiliki luas 4,7 hektar dengan kapasitas 2.029 TEUS, sedangkan area pemeriksaan bea cukai dengan kapasitas 1.068 TEUS.

TPS juga memiliki CFS (pergudangan) dengan luas $10.000 \mathrm{~m}^{2}$ dan tempat khusus barang berbahaya seluas $6.500 \mathrm{~m}^{2}$. Untuk mendukung operasional terminal, perusahaan menyediakan peralatan yang terdiri dari cassette, chassis, container crane, dolly system, forklift (electric dan diesel), head truck dan low bed chassis, RTF, reach stacker, reefer plug, sky stacker, dan translifter. TPS juga memiliki New TOS System terdiri dari TOS (Terminal Operating System) untuk kegiatan operasional dan C-TOS yang merupakan aplikasi untuk billing (nota rampung) yang digunakan untuk mengatur seluruh pergerakan petikemas. New TOS System menyediakan kondisi aktual dari kegiatan operasional serta menyediakan Pertukaran Data Elektronik. Kemudian juga terdapat fasilitas web access dan CLIQUE 247 yang terdapat di website resmi TPS, dimana para pengguna jasa bisa melakukan transaksi dan cetak dokumen secara online.
TPS menyediakan berbagai layanan antara lain penerimaan petikemas, pemuatan petikemas, pembongkaran petikemas, pengeluaran petikemas serta pelayanan lainnya. Perusahaan telah membuat SOP (standard operating procedure) yang harus dipahami oleh para pengguna terminal petikemas baik itu SOP penerimaan petikemas, pemuatan petikemas, pembongkaran petikemas, pengeluaran petikemas. SOP sendiri merupakan serangkaian panduan yang terdokumentasi secara jelas, lengkap, dan rinci mengenai proses, tugas, dan peran setiap individu atau kelompok yang dilakukan sehari-hari di dalam suatu organisasi yang berfungsi membentuk sistem kerja dan aliran kerja yang teratur, sistematis, serta dapat dipertanggungjawabkan dan menggambarkan bagaimana tujuan pekerjaan dilaksanakan sesuai dengan kebijakan dan peraturan yang berlaku (Rachmi et al., 2014).

SOP merupakan dokumen yang menjabarkan aktivitas operasional yang dilakukan sehari-hari, dengan tujuan agar pekerjaan tersebut dilakukan secara benar, tepat, dan konsisten, untuk menghasilkan produk sesuai standar yang telah ditetapkan sebelumnya (Tathagati, 2014). Hal senada juga disampaikan oleh Gabriele (2018), bahwa SOP merupakan pedoman atau acuan untuk melaksanakan tugas dan pekerjaaan sesuai dengan fungsi dari pekerjaan tersebut. Dengan adanya SOP semua kegiatan di suatu perusahaan dapat terancang dengan baik dan dapat berjalan sesuai kemauan perusahaan. Sehingga SOP akan membantu perusahaan untuk mencapai tujuan perusahaan. Sedangkan menurut Budihardjo (2014), SOP adalah suatu perangkat lunak pengatur, yang mengatur tahapan suatu proses kerja atau prosedur kerja tertentu. Menurut Santoso (2014), SOP terdiri dari 7 hal pokok yaitu efisiensi, konsisten, minimalisasi kesalahan, penyelesaian masalah, perlindungan tenaga kerja, peta kerja, dan batasan pertahanan.

Dengan demikian, adanya SOP yang dibuat oleh PT Terminal Petikemas Surabaya dalam proses layanan penerimaan petikemas, pemuatan petikemas, pembongkaran petikemas, pengeluaran petikemas diharapkan dapat mempermudah pengguna terminal petikemas dalam memenuhi kebutuhannya, namun pada kenyataanya SOP yang ada sulit untuk dipahami oleh para pengguna terminal petikemas sehingga membuat proses penerimaan, pemuatan, pembongkaran, dan pengeluaran petikemas memerlukan waktu yang cukup lama sehingga menimbulkan ketidakpuasan para pengguna terminal petikemas karena waktu tunggu yang lama dan membuat biaya yang dikeluarkan oleh perusahaan semakin tinggi. Hal ini senada dengan penelitian yang dilakukan oleh Bastyan (2017) di Terminal Petikemas Surabaya, bahwa seluruh dimensi kualitas layanan menghasilkan tingkat kepuasan "cukup puas" yang artinya bahwa pelanggan menilai pelayanan yang diberikan PT. TPS sudah cukup memenuhi harapan namun masih belum maksimal. Adapun beberapa hal yang perlu dilakukan perbaikan yaitu petugas administrasi agar memiliki kompetensi, petugas 
administrasi agar memberikan informasi jelas dan mudah dimengerti, jumlah petugas (administrasi, operasional tally, dan TKBM) memadai, lapangan penumpukan kontainer memadai dan layak, fasilitas umum dalam kondisi baik dan memadai, dan kemudahan dalam sistem pembayaran. Namun indikator yang memerlukan prioritas utama adalah indikator yang berhubungan dengan kompetensi petugas khususnya petugas administrasi. Sehingga rekomendasi pihak manajemen adalah dengan membuat SOP untuk setiap aktifitas di pelabuhan bagi petugas administrasi.

Adapun tujuan penelitian ini yaitu untuk memetakan SOP (standard operating procedure) pemasukan, pemuatan, pembongkaran dan pengeluaran petikemas di PT. Terminal Petikemas Surabaya. Dengan memetakan SOP dalam proses pemasukan, pemuatan, pembongkaran dan pengeluaran petikemas di PT. Terminal Petikemas Surabaya diharapkan dapat memudahkan para pengguna terminal petikemas Surabaya dalam memenuhi kebutuhannya.

\section{METODE PENELITIAN}

Penelitian berlokasi di Terminal Petikemas Surabaya yang dikelola oleh PT. Terminal Petikemas Surabaya. Metode dalam penelitian ini menggunakan analisis deskriptif. Adapun jenis data yang digunakan berasal dari data sekunder, dengan teknik pengumpulan data yang digunakan yakni studi dokumentasi atau kepustakaan. Data yang digunakan merupakan data yang telah tersedia di perusahaan yang bersumber dari website Terminal Petikemas Surabaya yakni tps.co.id. Selain itu juga, studi kepustakaan bertujuan untuk menggali data yang digunakan bersumber dari penelitian terdahulu atau sumber lainnya yang relevan (Somadi \& Hidayat, 2019).

\section{HASIL DAN PEMBAHASAN}

Layanan petikemas di Terminal Petikemas Surabaya terdiri dari layanan penerimaan petikemas, pemuatan petikemas, pembongkaran petikemas, dan pengeluaran petikemas. SOP (standard operating procedure) layanan pada proses penerimaan petikemas, pemuatan petikemas, pembongkaran petikemas, dan pengeluaran petikemas berbeda-beda sehingga harus dipahami oleh pengguna terminal petikemas.

SOP (standard operating procedure) layanan penerimaan petikemas di Terminal Petikemas Surabaya dimulai dari pengiriman data COPARN, pembuatan job order, pencetakan dan distribusi E-CEIR, pengemudi menuju gerbang masuk, penempelan $\mathrm{QR}$ code, menginput nomor polisi kendaraan dan BAT, konfirmasi nomor petikemas, pemeriksaan kesesuaian antara fisik dengan sistem, memasukan MGW dan nomor segel, perekaman berat truk dan muatan petikemas, konfirmasi proses pre gate-in, penempelan kartu identitas dan pengambilan job slip, pengemudi menuju lokasi penumpukan, pengiriman perintah kerja, pemindahan petikemas dari truk ke lapangan penumpukan, melakukan proses gate-out, penyerahan job slip dan menempelkan kartu identitas, penimbangan truk kembali, pengecekan VGM TPS, penghilanganflag stop, pengembalian dan pemberitahuan dokumen, Penyerahan bukti timbang, meninggalkan area TPS. Tabel berikut merupakan penjelasan SOP layanan penerimaan petikemas di Terminal Petikemas Surabaya.

Tabel 1. SOP Layanan Penerimaan Petikemas di Terminal Petikemas Surabaya

\begin{tabular}{|c|c|c|c|}
\hline Tahap & Aktivitas & Penjelasan & $\begin{array}{c}\text { Pihak Yang } \\
\text { Terlibat }\end{array}$ \\
\hline 1 & $\begin{array}{l}\text { Pengiriman } \\
\text { data } \\
\text { COPARN }\end{array}$ & $\begin{array}{l}\text { Perusahaan pelayara } \\
\mathrm{n} \text { mengirimkan data } \\
\text { COPARN ke PT. } \\
\text { Terminal Petikemas } \\
\text { Surabaya, baik } \\
\text { melalui web access } \\
\text { (file excel) maupun } \\
\text { melalui FTP (file } \\
\text { transfer protocol) / } \\
\text { file EDI. }\end{array}$ & $\begin{array}{c}\text { Perusahaan } \\
\text { pelayaran, } \\
\text { TPS }\end{array}$ \\
\hline 2 & $\begin{array}{l}\text { Pembuatan } \\
\text { job order }\end{array}$ & $\begin{array}{l}\text { Pengguna jasa } \\
\text { membuat job } \\
\text { order melalui } \\
\text { aplikasi Clique } 247 .\end{array}$ & $\begin{array}{l}\text { Pengguna } \\
\text { jasa }\end{array}$ \\
\hline 3 & $\begin{array}{l}\text { Pencetakan } \\
\text { E-CEIR }\end{array}$ & $\begin{array}{l}\text { Pengguna jasa } \\
\text { mencetak E-CEIR } \\
\text { (electronic } \\
\text { container equipment } \\
\text { interchange } \\
\text { receipt). }\end{array}$ & $\begin{array}{c}\text { Pengguna } \\
\text { jasa }\end{array}$ \\
\hline 4 & $\begin{array}{l}\text { Distribusi E- } \\
\text { CEIR }\end{array}$ & $\begin{array}{l}\text { Pengguna jasa } \\
\text { mendistribusikan E- } \\
\text { CEIR kepada } \\
\text { Pengemudi truk. }\end{array}$ & $\begin{array}{l}\text { Pengguna } \\
\text { jasa, } \\
\text { Pengemudi } \\
\text { truk }\end{array}$ \\
\hline 5 & $\begin{array}{l}\text { Pengemudi } \\
\text { menuju } \\
\text { gerbang } \\
\text { masuk }\end{array}$ & $\begin{array}{l}\text { Pengemudi truk } \\
\text { menuju ke gate- } \\
\text { in (gerbang masuk) } \\
\text { bersama } \\
\text { petikemasnya. }\end{array}$ & $\begin{array}{l}\text { Pengemudi } \\
\text { truk }\end{array}$ \\
\hline 6 & $\begin{array}{l}\text { Penempelan } \\
\text { QR Code }\end{array}$ & $\begin{array}{l}\text { Pengemudi truk } \\
\text { menempelkan QR- } \\
\text { Code yang terdapat } \\
\text { pada E-CEIR ke } \\
\text { QR-Code Reader } \\
\text { yang ada di gate. }\end{array}$ & $\begin{array}{l}\text { Pengemudi } \\
\text { truk }\end{array}$ \\
\hline 7 & $\begin{array}{l}\text { Menginput } \\
\text { nomor polisi } \\
\text { kendaraan } \\
\text { dan BAT }\end{array}$ & $\begin{array}{l}\text { Petugas Tally Pre } \\
\text { Gate-In } \\
\text { memasukkan nomor } \\
\text { polisi truk dan } \\
\text { nomor BAT dan } \\
\text { mengkonfirmasi } \\
\text { nomor petikemas } \\
\text { melalui HHT. }\end{array}$ & $\begin{array}{c}\text { Petugas } \\
\text { Tally } \\
\text { Pre Gate-In }\end{array}$ \\
\hline 8 & $\begin{array}{l}\text { Konfirmasi } \\
\text { nomor } \\
\text { petikemas }\end{array}$ & $\begin{array}{l}\text { Petugas Tally } \\
\text { Pre Gate-In } \\
\text { mengkonfirmasi } \\
\text { nomor petikemas } \\
\text { melalui HHT. }\end{array}$ & $\begin{array}{c}\text { Petugas } \\
\text { Tally } \\
\text { Pre Gate-In }\end{array}$ \\
\hline 9 & $\begin{array}{l}\text { Pemeriksaan } \\
\text { kesesuaian } \\
\text { antara fisik } \\
\text { dengan } \\
\text { sistem }\end{array}$ & $\begin{array}{l}\text { Setelah informasi } \\
\text { detil petikemas } \\
\text { tampil pada HHT, } \\
\text { Petugas Tally Pre } \\
\text { Gate-In memeriksa } \\
\text { kesesuaian antara } \\
\text { fisik dan informasi }\end{array}$ & $\begin{array}{c}\text { Petugas } \\
\text { Tally } \\
\text { Pre Gate-In, } \\
\text { Pengemudi } \\
\text { truk, } \\
\text { Superintend } \\
\text { en Gate, } \\
\text { Perusahaan }\end{array}$ \\
\hline
\end{tabular}




\begin{tabular}{|c|c|c|c|}
\hline Tahap & Aktivitas & Penjelasan & $\begin{array}{c}\text { Pihak Yang } \\
\text { Terlibat }\end{array}$ \\
\hline & & 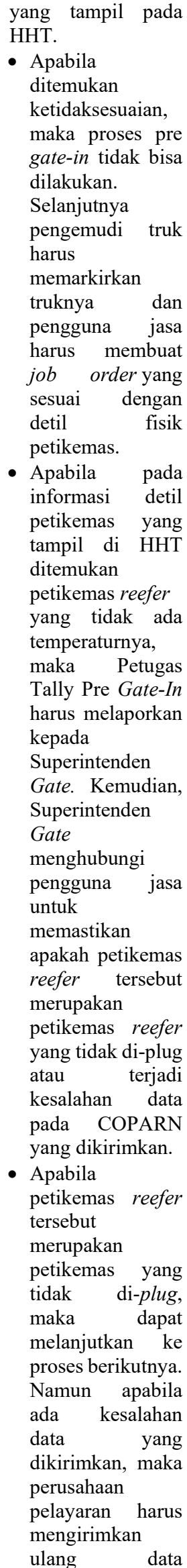 & $\begin{array}{c}\text { pelayaran, } \\
\text { pengguna } \\
\text { jasa }\end{array}$ \\
\hline
\end{tabular}

\begin{tabular}{|c|c|c|c|}
\hline Tahap & Aktivitas & Penjelasan & $\begin{array}{c}\text { Pihak Yang } \\
\text { Terlibat }\end{array}$ \\
\hline & & $\begin{array}{lr}\text { COPARN } & \text { yang } \\
\text { benar } & \text { dan } \\
\text { pengguna } & \text { jasa } \\
\text { harus membuat } & \text { job order yang } \\
\text { sesuai r dengan } \\
\text { data rasik } \\
\text { petikemas. }\end{array}$ & \\
\hline 10 & $\begin{array}{l}\text { Memasukan } \\
\text { MGW dan } \\
\text { nomor segel }\end{array}$ & $\begin{array}{l}\text { Petugas Tally Pre } \\
\text { Gate-In } \\
\text { memasukkan MGW } \\
\text { (maximum gross } \\
\text { weight) dan nomor } \\
\text { segel }\end{array}$ & $\begin{array}{c}\text { Petugas } \\
\text { Tally } \\
\text { Pre Gate-In }\end{array}$ \\
\hline 11 & $\begin{array}{l}\text { Perekaman } \\
\text { berat truk } \\
\text { dan muatan } \\
\text { petikemas }\end{array}$ & $\begin{array}{ll}\text { Petugas } & \text { Tally } \\
\text { Pre Gate-In } \\
\text { menekan tombol } \\
\text { Refresh pada HHT } \\
\text { untuk merekam } \\
\text { berat truk dan } \\
\text { muatan } \\
\text { petikemasnya. } \\
\end{array}$ & $\begin{array}{c}\text { Petugas } \\
\text { Tally } \\
\text { Pre Gate-In }\end{array}$ \\
\hline 12 & $\begin{array}{l}\text { Konfirmasi } \\
\text { proses } \\
\text { pre gate-in }\end{array}$ & $\begin{array}{l}\text { Petugas Tally Pre } \\
\text { Gate-In menekan } \\
\text { tombol Confirm } \\
\text { pada HHT untuk } \\
\text { mengkonfirmasi } \\
\text { proses pre gate-in. }\end{array}$ & $\begin{array}{c}\text { Petugas } \\
\text { Tally } \\
\text { Pre Gate-In }\end{array}$ \\
\hline 13 & $\begin{array}{l}\text { Penempelan } \\
\text { kartu } \\
\text { identitas dan } \\
\text { pengambilan } \\
\text { job slip }\end{array}$ & 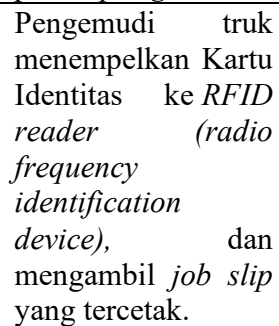 & $\begin{array}{l}\text { Pengemudi } \\
\text { truk }\end{array}$ \\
\hline 14 & $\begin{array}{l}\text { Pengemudi } \\
\text { menuju } \\
\text { lokasi } \\
\text { penumpukan }\end{array}$ & $\begin{array}{l}\text { Pengemudi truk } \\
\text { menuju ke lokasi } \\
\text { penumpukan yang } \\
\text { sesuai dengan yang } \\
\text { tertulis padajob } \\
\text { slip. }\end{array}$ & $\begin{array}{l}\text { Pengemudi } \\
\text { truk }\end{array}$ \\
\hline 15 & $\begin{array}{l}\text { Pengiriman } \\
\text { perintah } \\
\text { kerja }\end{array}$ & $\begin{array}{l}\text { Setelah pengemudi } \\
\text { truk sampai di lokasi } \\
\text { penumpukan, Yard } \\
\text { Dispatcher } \\
\text { mengirimkan } \\
\text { perintah } \\
\text { kepada } \quad \text { kTGja } \\
\text { melalui } r \text { VMT } \\
\text { (vehicle mounted } \\
\text { terminal) untuk } \\
\text { memindahkan } \\
\text { petikemas dari truk } \\
\text { ke lapangan } \\
\text { penumpukan. }\end{array}$ & $\begin{array}{c}\text { Yard } \\
\text { Dispatcher, } \\
\text { RTG/RS }\end{array}$ \\
\hline 16 & $\begin{array}{l}\text { Pemindahan } \\
\text { petikemas } \\
\text { dari truk ke } \\
\text { lapangan } \\
\text { penumpukan }\end{array}$ & $\begin{array}{l}\text { Operator RTG/RS } \\
\text { memindahkan } \\
\text { petikemas dari truk } \\
\text { ke lapangan } \\
\text { penumpukan sesuai } \\
\text { dengan instruksi } \\
\text { yang ditampilkan } \\
\text { pada VMT. }\end{array}$ & $\begin{array}{c}\text { Operator } \\
\text { RTG/RS, } \\
\text { Pengemudi } \\
\text { truk }\end{array}$ \\
\hline
\end{tabular}




\begin{tabular}{|c|c|c|c|}
\hline Tahap & Aktivitas & Penjelasan & $\begin{array}{c}\text { Pihak Yang } \\
\text { Terlibat } \\
\end{array}$ \\
\hline 17 & $\begin{array}{l}\text { Melakukan } \\
\text { proses gate- } \\
\text { out }\end{array}$ & 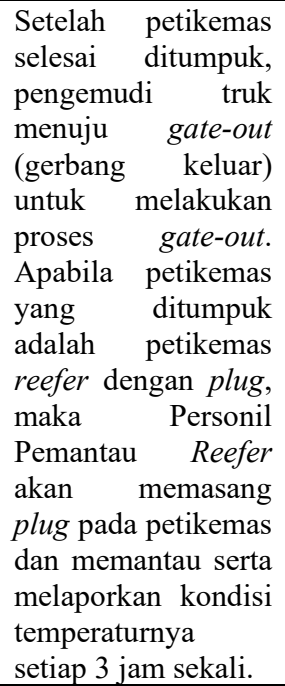 & $\begin{array}{l}\text { Pengemudi } \\
\text { truk dan } \\
\text { personil } \\
\text { pemantau re } \\
\text { efer }\end{array}$ \\
\hline 18 & $\begin{array}{l}\text { Penyerahan } \\
\text { job slip dan } \\
\text { menempelka } \\
\mathrm{n} \quad \text { kartu } \\
\text { identitas }\end{array}$ & $\begin{array}{l}\text { Pengemudi truk } \\
\text { menyerahkan job } \\
\text { slip kepada Personil } \\
\text { Gate dan } \\
\text { menempelkan Kartu } \\
\text { Identitas ke RFID } \\
\text { Reader. }\end{array}$ & $\begin{array}{l}\text { Pengemudi } \\
\text { truk, } \\
\text { Personil } \\
\text { gate }\end{array}$ \\
\hline 19 & $\begin{array}{l}\text { Penimbanga } \\
\mathrm{n} \text { truk } \\
\text { kembali }\end{array}$ & \begin{tabular}{lr}
\multicolumn{3}{c}{ Sesampainya di } \\
jembatan timbang, \\
truk akan ditimbang \\
kembali ran \\
hasilnya akan \\
tercatat di sistem PT. \\
Terminal Petikemas \\
Surabaya setelah \\
proses dikonfirmasi. \\
Penghitungan berat \\
petikemas dilakukan \\
dengan mengurangi \\
berat saat gate- \\
in (truk \\
petikemas) dengan \\
berat saat gate-out \\
(truk).
\end{tabular} & $\begin{array}{l}\text { Pengemudi } \\
\text { truk, } \\
\text { Petugas } \\
\text { jembatan } \\
\text { timbang }\end{array}$ \\
\hline 20 & $\begin{array}{l}\text { Pengecekan } \\
\text { VGM TPS }\end{array}$ & $\begin{array}{l}\text { Setelah proses gate- } \\
\text { out dikonfirmasi, } \\
\text { secara otomatis } \\
\text { sistem akan } \\
\text { mengecek apakah } \\
\text { pengguna jasa } \\
\text { memilih VGM TPS } \\
\text { atau tidak saat } \\
\text { pembuatan job } \\
\text { order. } \\
\text { a.Bagi pengguna } \\
\text { jasa yang memilih } \\
\text { menggunakan } \\
\text { VGM TPS maka } \\
\text { hasil panim } \\
\text { penimbangan dari } \\
\text { TPS akan } \\
\text { digunakan } \\
\text { sebagai data } \\
\text { VGM bersama } \\
\text { dengan tanda } \\
\text { tangan yang sah. }\end{array}$ & $\begin{array}{l}\text { Pengguna } \\
\text { jasa, TPS, } \\
\text { perusahaan } \\
\text { pelayaran }\end{array}$ \\
\hline
\end{tabular}

\begin{tabular}{|c|c|c|c|}
\hline Tahap & Aktivitas & Penjelasan & $\begin{array}{c}\text { Pihak Yang } \\
\text { Terlibat }\end{array}$ \\
\hline & & 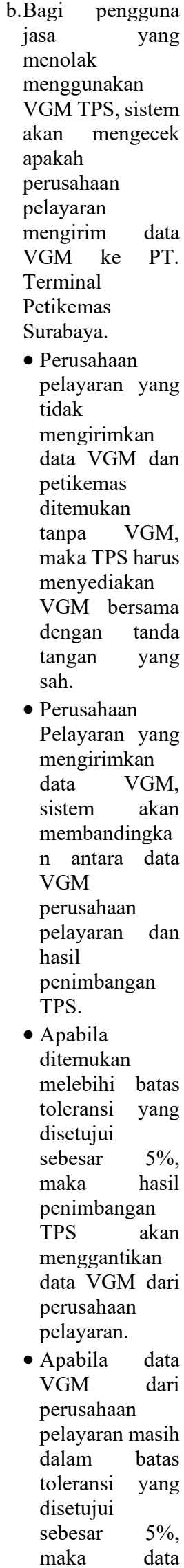 & \\
\hline
\end{tabular}




\begin{tabular}{|c|c|c|c|}
\hline Tahap & Aktivitas & Penjelasan & $\begin{array}{c}\text { Pihak Yang } \\
\text { Terlibat }\end{array}$ \\
\hline & & $\begin{array}{l}\text { tersebut yang } \\
\text { akan digunakan }\end{array}$ & \\
\hline 21 & $\begin{array}{l}\text { Penghilanga } \\
\mathrm{n} \text { flag stop }\end{array}$ & $\begin{array}{lr}\text { Ketika data VGM } \\
\text { telah diperoleh, } \\
\text { sistem r akan } \\
\text { menghilangkan } \text { flag } \\
\text { stop. }\end{array}$ & TPS \\
\hline 22 & $\begin{array}{l}\text { Pengembalia } \\
\mathrm{n} \text { dan } \\
\text { pemberitahu } \\
\text { an dokumen }\end{array}$ & $\begin{array}{l}\text { Sistem TPS akan } \\
\text { mengembalikan } \\
\text { secara otomatis EDI } \\
\text { FILE (CODECO, } \\
\text { VERMAS) untuk } \\
\text { petikemas dengan } \\
\text { VGM TPS dan } \\
\text { mengirimkan } \\
\text { pemberitahuan via } \\
\text { email kepada } \\
\text { perusahaan } \\
\text { pelayaran apabila } \\
\text { data VGM telah } \\
\text { diperoleh. }\end{array}$ & $\begin{array}{c}\text { TPS, } \\
\text { Perusahaan } \\
\text { pelayaran }\end{array}$ \\
\hline 23 & $\begin{array}{l}\text { Penyerahan } \\
\text { bukti } \\
\text { timbang }\end{array}$ & $\begin{array}{l}\text { Personil Gate } \\
\text { menyerahkan bukti } \\
\text { timbang kepada } \\
\text { Pengemudi truk. }\end{array}$ & $\begin{array}{l}\text { Personil } \\
\text { gate, } \\
\text { Pengemudi } \\
\text { truk }\end{array}$ \\
\hline 24 & $\begin{array}{l}\text { Meninggalka } \\
\mathrm{n} \text { area TPS }\end{array}$ & $\begin{array}{l}\text { Pengemudi truk } \\
\text { keluar } \\
\text { meninggalkan area } \\
\text { Terminal Petikemas } \\
\text { Surabaya. }\end{array}$ & $\begin{array}{l}\text { Pengemudi } \\
\text { truk }\end{array}$ \\
\hline
\end{tabular}

Sumber: Hasil pengolahan data, 2020

Sementara itu, SOP layanan pemuatan petikemas di Terminal Petikemas Surabaya dimulai dari pengiriman dokumen, penerimaan dan pemeriksaan dokumen, pembuatan dokumen rapat harian operasional, mengadakan rapat harian operasional, perencanaan pemuatan petikemas, permintaan persetujuan rencana pemuatan petikemas, mencetak dan mendisribusikan rencana pemuatan akhir, pengiriman perintah kerja, pemindahan petikemas dari lapangan penumpukan ke truk, membawa petikemas menuju dermaga, pemasangan twistlock, pemberian informasi untuk pemindahan petikemas dari truk ke kapal, konfirmasi muatan, pemasangan plug dan pengaturan temperatur, pemasangan lashing, pelepasan tali temali pada kapal, dan konfirmasi keberangkatan kapal. Tabel berikut merupakan SOP layanan pemuatan petikemas di Terminal Petikemas Surabaya.

Tabel 2. SOP Layanan Pemuatan Petikemas Di Terminal Petikemas Surabaya

\begin{tabular}{|c|l|l|l|}
\hline Tahap & Aktivitas & \multicolumn{1}{|c|}{ Penjelasan } & $\begin{array}{l}\text { Pihak Yang } \\
\text { Terlibat }\end{array}$ \\
\hline 1 & $\begin{array}{l}\text { Pengiriman } \\
\text { dokumen }\end{array}$ & $\begin{array}{l}\text { Perusahaan } \\
\text { pelayaran } \\
\text { mengirimkan } \\
\text { dokumen-dokumen } \\
\text { yang terkait dengan } \\
\text { pemuatan petikemas } \\
\text { antara lain: }\end{array}$ & $\begin{array}{l}\text { Perusahaan } \\
\text { pelayaran, } \\
\text { TPS }\end{array}$ \\
& & $\begin{array}{l}\text { Master Cable } \\
\text { a. Pemberitahuan }\end{array}$ & \\
& & b. Identifikasi & \\
& & & \\
\hline
\end{tabular}

\begin{tabular}{|c|c|c|c|}
\hline Tahap & Aktivitas & Penjelasan & $\begin{array}{c}\text { Pihak Yang } \\
\text { Terlibat } \\
\end{array}$ \\
\hline & & $\begin{array}{ll} & \text { Kapal } \\
& \text { Petikemas } \\
\text { c. } & \text { Pernyataan } \\
\text { d. } & \text { Fakta } \\
\text { d. } & \text { Daftar } \\
& \text { Ringkasan } \\
& \text { Ekspor } \\
\text { e. } & \text { Daftar Kargo } \\
\text { f. } & \text { Berbahaya } \\
\text { Daftar Urutan } & \text { Crane } \\
\text { g. } & \text { Rencana } \\
& \text { Umum } \\
\text { Pemuatan } \\
\text { h. } \\
\text { Bay Plan } \\
\text { i. Pemuatan } \\
\text { Manifest }\end{array}$ & \\
\hline 2 & $\begin{array}{l}\text { Penerimaan } \\
\text { dan } \\
\text { pemeriksaan } \\
\text { dokumen }\end{array}$ & $\begin{array}{ll}\text { Personil } & \\
\text { Perencanaan } & \\
\text { Dermaga menerima } \\
\text { dokumen dari } \\
\text { perusahaan } \\
\text { pelayaran dan } \\
\text { memeriksa } \\
\text { kelengkapannya. } \\
\end{array}$ & $\begin{array}{l}\text { Personil } \\
\text { Perencanaan } \\
\text { Dermaga, } \\
\text { Perusahaan } \\
\text { pelayaran }\end{array}$ \\
\hline 3 & $\begin{array}{l}\text { Pembuatan } \\
\text { dokumen } \\
\text { rapat harian } \\
\text { operasional }\end{array}$ & $\begin{array}{l}\text { Personil } \\
\text { Perencanaan } \\
\text { Dermaga } \\
\text { mempersiapkan } \\
\text { dokumen untuk } \\
\text { rapat harian } \\
\text { operasional. }\end{array}$ & $\begin{array}{l}\text { Personil } \\
\text { Perencanaan } \\
\text { Dermaga }\end{array}$ \\
\hline 4 & $\begin{array}{l}\text { Mengadakan } \\
\text { rapat harian } \\
\text { operasional }\end{array}$ & $\begin{array}{l}\text { Departemen Operasi } \\
\text { bersama } \\
\text { Departemen Teknik } \\
\text { mengadakan rapat } \\
\text { harian operasional } \\
\text { untuk merencanakan } \\
\text { kegiatan bongkar } \\
\text { muat. }\end{array}$ & $\begin{array}{l}\text { Departemen } \\
\text { Operasi, } \\
\text { Departemen } \\
\text { Teknik }\end{array}$ \\
\hline 5 & $\begin{array}{l}\text { Perencanaan } \\
\text { pemuatan } \\
\text { petikemas }\end{array}$ & $\begin{array}{l}\text { Personil Perencana } \\
\text { Kapal } \\
\text { merencanakan } \\
\text { pemuatan petikemas } \\
\text { berdasarkan } \\
\text { instruksi } \\
\text { penyimpanan yang } \\
\text { diterima dari } \\
\text { perusahaan } \\
\text { pelayaran. }\end{array}$ & $\begin{array}{l}\text { Personil } \\
\text { Perencana } \\
\text { Kapal, } \\
\text { Perusahaan } \\
\text { pelayaran }\end{array}$ \\
\hline 6 & $\begin{array}{l}\text { Permintaan } \\
\text { persetujuan } \\
\text { rencana } \\
\text { pemuatan } \\
\text { petikemas }\end{array}$ & $\begin{array}{l}\text { Personil Perencana } \\
\text { Kapal meminta } \\
\text { persetujuan rencana } \\
\text { pemuatan petikemas } \\
\text { kepada Chief } \\
\text { Officer. Apabila } \\
\text { Chief Officer telah } \\
\text { menyetujui rencana } \\
\text { pemuatan } \\
\text { petikemas, Petugas } \\
\text { Perencana Kapal } \\
\text { memproses rencana } \\
\text { pemuatan akhir } \\
\text { menjadi file PDF } \\
\text { dan menyimpannya }\end{array}$ & $\begin{array}{l}\text { Personil } \\
\text { Perencana } \\
\text { Kapal, Chief } \\
\text { Officer }\end{array}$ \\
\hline
\end{tabular}




\begin{tabular}{|c|c|c|c|}
\hline Tahap & Aktivitas & Penjelasan & $\begin{array}{c}\text { Pihak Yang } \\
\text { Terlibat }\end{array}$ \\
\hline & & $\begin{array}{lr}\text { di folder grup agar } \\
\text { bisa diakses oleh } \\
\text { pihak lain yang } \\
\text { bekepentingan } \\
\text { terhadap } & \text { file } \\
\text { tersebut. } & \\
\end{array}$ & \\
\hline 7 & $\begin{array}{l}\text { Mencetak } \\
\text { dan } \\
\text { mendisribusi } \\
\text { kan rencana } \\
\text { pemuatan } \\
\text { akhir }\end{array}$ & 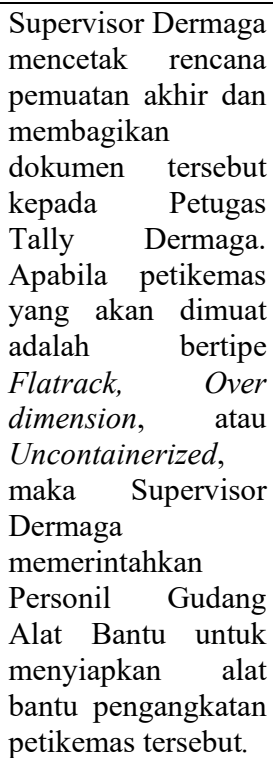 & $\begin{array}{l}\text { Supervisor } \\
\text { Dermaga, } \\
\text { Petugas } \\
\text { Tally } \\
\text { Dermaga, } \\
\text { Personil } \\
\text { Gudang Alat } \\
\text { Bantu }\end{array}$ \\
\hline 8 & $\begin{array}{l}\text { Pengiriman } \\
\text { perintah } \\
\text { kerja }\end{array}$ & $\begin{array}{l}\text { Vessel Dispatcher } \\
\text { mengirimkan } \\
\text { perintah kerja } \\
\text { kepada VMT di } \\
\text { masing-masing alat } \\
\text { dan HHT. }\end{array}$ & $\begin{array}{c}\text { Vessel } \\
\text { Dispatcher }\end{array}$ \\
\hline 9 & $\begin{array}{l}\text { Pemindahan } \\
\text { petikemas } \\
\text { dari } \\
\text { lapangan } \\
\text { penumpukan } \\
\text { ke truk }\end{array}$ & $\begin{array}{lr}\text { Operator } & \text { RTG/RS } \\
\text { memindahkan } & \\
\text { petikemas } & \text { dari } \\
\text { lapangan } & \\
\text { penumpukan ke truk } \\
\text { sesuai } & \text { dengan } \\
\text { instruksi r yang } \\
\text { ditampilkan } \\
\text { VMT. }\end{array}$ & $\begin{array}{c}\text { Operator } \\
\text { RTG/RS, } \\
\text { Pengemudi } \\
\text { truk }\end{array}$ \\
\hline 10 & $\begin{array}{l}\text { Membawa } \\
\text { petikemas } \\
\text { menuju } \\
\text { dermaga }\end{array}$ & $\begin{array}{lr}\text { Pengemudi } & \text { truk } \\
\text { membawa } & \\
\text { petikemas menuju } \\
\text { dermaga sesuai } \\
\text { dengan instruksi } \\
\text { yang ditampilkan } \\
\text { pada VMT. }\end{array}$ & $\begin{array}{l}\text { Pengemudi } \\
\text { truk }\end{array}$ \\
\hline 11 & $\begin{array}{l}\text { Pemasangan } \\
\text { twistlock }\end{array}$ & 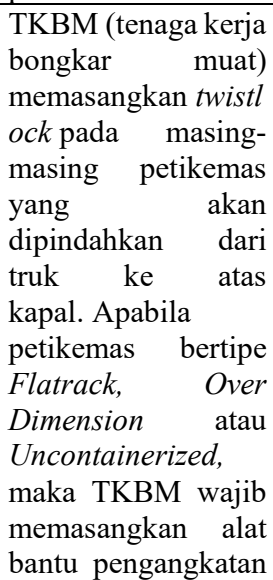 & $\begin{array}{c}\text { TKBM, } \\
\text { Pengemudi } \\
\text { truk }\end{array}$ \\
\hline
\end{tabular}

\begin{tabular}{|c|c|c|c|}
\hline Tahap & Aktivitas & Penjelasan & $\begin{array}{c}\text { Pihak Yang } \\
\text { Terlibat }\end{array}$ \\
\hline & & $\begin{array}{lr}\text { yang } & \text { telah } \\
\text { disediakan } & \text { sebelum } \\
\text { petikemas diangkat } \\
\text { ke atas kapal. }\end{array}$ & \\
\hline 12 & $\begin{array}{l}\text { Pemberian } \\
\text { informasi } \\
\text { untuk } \\
\text { pemindahan } \\
\text { petikemas } \\
\text { dari truk ke } \\
\text { kapal }\end{array}$ & $\begin{array}{l}\text { Petugas Tally } \\
\text { Dermaga } \\
\text { menginformasikan } \\
\text { kepada Operator CC } \\
\text { untuk memindahkan } \\
\text { petikemas dari truk } \\
\text { ke atas kapal sesuai } \\
\text { dengan rencana } \\
\text { pemuatan. }\end{array}$ & $\begin{array}{c}\text { Petugas } \\
\text { Tally } \\
\text { Dermaga, } \\
\text { Operator } \\
\text { CC, } \\
\text { Pengemudi } \\
\text { truk }\end{array}$ \\
\hline 13 & $\begin{array}{l}\text { Konfirmasi } \\
\text { muatan }\end{array}$ & $\begin{array}{lr}\text { Setelah petikemas } \\
\text { diletakkan pada } \\
\text { lokasi di atas kapal } \\
\text { sesuai } \\
\text { rencana pemuatan, } \\
\text { Petugas } \\
\text { Dermaga } \\
\text { mengkonfirmasi } \\
\text { pemuatan telah } \\
\text { dilakukan melalui } \\
\text { HHT. }\end{array}$ & $\begin{array}{l}\text { Petugas } \\
\text { Tally } \\
\text { Dermaga }\end{array}$ \\
\hline 14 & $\begin{array}{l}\text { Pemasangan } \\
\text { plug dan } \\
\text { pengaturan } \\
\text { temperatur }\end{array}$ & $\begin{array}{l}\text { Apabila petikemas } \\
\text { bertipe reefer, maka } \\
\text { Personil Pemantau } \\
\text { Reefer akan } \\
\text { memasang plug } \\
\text { pada petikemas } \\
\text { tersebut dan } \\
\text { memeriksa } \\
\text { pengaturan } \\
\text { temperatur. }\end{array}$ & $\begin{array}{c}\text { Pemantau } R \\
\text { eefer }\end{array}$ \\
\hline 15 & $\begin{array}{l}\text { Pemasangan } \\
\text { lashing }\end{array}$ & $\begin{array}{lr}\text { TKBM memasang } \\
\text { lashing pada } \\
\text { petikemas yang } \\
\text { telah dimuat ke atas } \\
\text { kapal. } \\
\end{array}$ & TKBM \\
\hline 16 & $\begin{array}{l}\text { Pelepasan } \\
\text { tali temali } \\
\text { pada kapal }\end{array}$ & $\begin{array}{l}\text { Apabila seluruh } \\
\text { petikemas telah } \\
\text { dimuat ke atas kapal } \\
\text { dan kapal siap untuk } \\
\text { diberangkatkan, } \\
\text { TKBM melepaskan } \\
\text { tali temali pada } \\
\text { kapal. }\end{array}$ & TKBM \\
\hline 17 & $\begin{array}{l}\text { Konfirmasi } \\
\text { keberangkat } \\
\text { an kapal }\end{array}$ & $\begin{array}{l}\text { Supervisor Dermaga } \\
\text { mengkonfirmasikan } \\
\text { keberangkatan kapal } \\
\text { ke dalam sistem } \\
\text { CTOS. }\end{array}$ & $\begin{array}{c}\text { Supervisor } \\
\text { Dermaga }\end{array}$ \\
\hline
\end{tabular}

Sumber: Hasil pengolahan data, 2020

Untuk SOP layanan pembongkaran petikemas di Terminal Petikemas Surabaya dimulai dari menyiapkan kade meter dan memberi tanda batas tambat kapal, siaga dan memasukan ujung tali tambat kapal, menginput data ke dalam sistem, penurunan tangga kapal dan pemasangan jala pengaman, pengecekan extra gangway, pembukaan lashing dan twislock petikemas, mengaktifkan dan mengirimkan urutan pembongkaran petikemas, pelaksanaan perlakuan khusus untuk petikemas tertentu, pembongkaran petikemas dari kapal 
ke atas truk, pemeriksaan secara visual kondisi fisik dan nomor petikemas, konfirmasi dan penginputan hasil pembongkaran, pengangkutan petikemas dari dermaga ke lapangan penumpukan, pemindahkan petikemas dari chassis head truck ke lokasi penumpukan, pemasangan kabel reefer dan pengaturan temperatur, penumpukan petikemas di lapangan penumpukan. Tabel berikut ini merupakan SOP layanan pembongkaran petikemas di Terminal Petikemas Surabaya.

Tabel 3. SOP Layanan Pembongkaran Petikemas Di Terminal Petikemas Surabaya

\begin{tabular}{|c|c|c|c|}
\hline Tahap & Aktivitas & Penjelasan & $\begin{array}{c}\text { Pihak Yang } \\
\text { Terlibat }\end{array}$ \\
\hline 1 & $\begin{array}{l}\text { Menyiapkan } \\
\text { kade meter } \\
\text { dan memberi } \\
\text { tanda batas } \\
\text { tambat kapal }\end{array}$ & $\begin{array}{l}\text { Berdasarkan } \\
\text { hasil rapat harian } \\
\text { rencana tambat } \\
\text { kapal, Supervisor } \\
\text { Dermaga } \\
\text { menyiapkan kade } \\
\text { meter dan memberi } \\
\text { tanda batas tambat } \\
\text { kapal dengan } \\
\text { menempatkan } \\
\text { bendera tambat di } \\
\text { dermaga untuk siang } \\
\text { hari } \\
\text { menambahkan } \\
\text { lampu tambat untuk } \\
\text { malam hari. }\end{array}$ & $\begin{array}{c}\text { Supervisor } \\
\text { Dermaga }\end{array}$ \\
\hline 2 & $\begin{array}{l}\text { Siaga dan } \\
\text { memasukan } \\
\text { ujung tali } \\
\text { tambat kapal }\end{array}$ & $\begin{array}{l}\text { TKBM bersiap pada } \\
\text { posisi kade meter } \\
\text { awal dan kade meter } \\
\text { akhir tempat kapal } \\
\text { akan sandar dan } \\
\text { memasukkan ujung } \\
\text { tali tambat kapal ke } \\
\text { dalam bolder. }\end{array}$ & TKBM \\
\hline 3 & $\begin{array}{l}\text { Menginput } \\
\text { data ke dalam } \\
\text { sistem }\end{array}$ & $\begin{array}{l}\text { Supervisor Dermag } \\
\text { a menginput data } \\
\text { tanggal, jam, dan } \\
\text { posisi sandar kapal } \\
\text { ke dalam sistem PT. } \\
\text { Terminal Petikemas } \\
\text { Surabaya. }\end{array}$ & $\begin{array}{c}\text { Supervisor } \\
\text { Dermaga }\end{array}$ \\
\hline 4 & $\begin{array}{l}\text { Penurunan } \\
\text { tangga kapal } \\
\text { dan } \\
\text { pemasangan } \\
\text { jala pengaman }\end{array}$ & $\begin{array}{lr}\text { Setelah } & \text { kapal } \\
\text { sandar, Kru } & \text { Kapal } \\
\text { menurunkan } & \text { tangga } \\
\text { kapal } & \text { dan } \\
\text { memasang } & \text { jala } \\
\text { pengaman. } & \\
\end{array}$ & Kru Kapal \\
\hline 5 & $\begin{array}{l}\text { Pengecekan } \\
\text { extra } \\
\text { gangway }\end{array}$ & $\begin{array}{l}\text { TKBM memastikan } \\
\text { extra gangway telah } \\
\text { dipasang dengan } \\
\text { benar dan aman } \\
\text { di antara tangga } \\
\text { kapal dan dermaga. }\end{array}$ & TKBM \\
\hline 6 & $\begin{array}{l}\text { Pembukaan } \\
\text { lashing dan } \\
\text { twislock } \\
\text { petikemas }\end{array}$ & $\begin{array}{l}\text { Pada saat kapal awal } \\
\text { sandar, TKBM } \\
\text { membuka lashing } \\
\text { dan twislock } \\
\text { petikemas di atas } \\
\text { dek pada Bay yang } \\
\text { akan dibongkar. } \\
\text { Pada saat membuka } \\
\text { lashing dan twislock } \\
\text { petikemas, TKBM }\end{array}$ & TKBM \\
\hline
\end{tabular}

\begin{tabular}{|c|c|c|c|}
\hline Tahap & Aktivitas & Penjelasan & $\begin{array}{c}\text { Pihak Yang } \\
\text { Terlibat }\end{array}$ \\
\hline & & $\begin{array}{l}\text { wajib menggunakan } \\
\text { mancage apabila } \\
\text { berada di atas } \\
\text { petikemas dengan } \\
\text { ketinggian lebih dari } \\
2 \text { meter. }\end{array}$ & \\
\hline 7 & $\begin{array}{l}\text { Mengaktifkan } \\
\text { dan } \\
\text { mengirimkan } \\
\text { urutan } \\
\text { pembongkara } \\
\text { n petikemas }\end{array}$ & \begin{tabular}{lr}
\multicolumn{2}{l}{ Vessel Dispatcher } \\
mengaktifkan dan \\
mengirimkan urutan \\
pembongkaran \\
petikemas. Urutan \\
ini disesuaikan \\
dengan r urutan \\
rencana bongkar \\
yang telah \\
disepakati dengan \\
perusahaan \\
pelayaran/ \\
kapal.
\end{tabular} & $\begin{array}{c}\text { Vessel } \\
\text { Disptacher, } \\
\text { Perusahaan } \\
\text { pelayaran/A } \\
\text { gen kapal }\end{array}$ \\
\hline 8 & $\begin{array}{l}\text { Pelaksanaan } \\
\text { perlakuan } \\
\text { khusus untuk } \\
\text { petikemas } \\
\text { tertentu }\end{array}$ & $\begin{array}{l}\text { Sebelum petikemas } \\
\text { dibongkar dari atas } \\
\text { kapal, harus } \\
\text { diperhatikan adanya } \\
\text { perlakuan khusus } \\
\text { untuk petikemas } \\
\text { bertipe Reefer, Over } \\
\text { Dimension dan } \\
\text { Uncontainerized } \\
\text { a. Petikemas } \\
\text { Reefer } \\
\text { - Personil } \\
\text { Pemantau } \\
\text { Reefer } \\
\text { melepas } \\
\text { kabel reefer } \\
\text { dari plug } \\
\text { kapal dan } \\
\text { mengecek } \\
\text { pengaturan } \\
\text { temperatur. } \\
\text { Petikemas } \\
\text { Over } \\
\text { Dimension dan } \\
\text { Uncontaineriz } \\
\text { ed } \\
\text { - Supervisor } \\
\text { dermaga } \\
\text { menginstru } \\
\text { ksikan } \\
\text { Petugas } \\
\text { Gudang } \\
\text { Alat Bantu } \\
\text { untuk } \\
\text { mempersiap } \\
\text { kan alat } \\
\text { bantu yang } \\
\text { dibutuhkan } \\
\text { untuk } \\
\text { membongk } \\
\text { ar petikemas } \\
\text { dari atas } \\
\text { memgan } \\
\text { berhati }\end{array}$ & $\begin{array}{c}\text { Personil } \\
\text { Pemantau } \\
\text { Reefer, } \\
\text { Supervisor } \\
\text { dermaga, } \\
\text { Petugas } \\
\text { Gudang } \\
\text { Alat Bantu, } \\
\text { TKBM }\end{array}$ \\
\hline
\end{tabular}




\begin{tabular}{|c|c|c|c|}
\hline Tahap & Aktivitas & Penjelasan & $\begin{array}{c}\text { Pihak Yang } \\
\text { Terlibat }\end{array}$ \\
\hline & & $\begin{array}{l}\text { kan } \\
\text { panjang, } \\
\text { lebar, dan } \\
\text { tinggi } \\
\text { petikemas. } \\
\text { - } \\
\text { Petugas } \\
\text { Gudang } \\
\text { Alat Bantu } \\
\text { mempersiap } \\
\text { kan alat } \\
\text { bantu untuk } \\
\text { membongk } \\
\text { ar } \\
\text { petikemas } \\
\text { sesuai } \\
\text { dengan } \\
\text { instruksi } \\
\text { dari Superv } \\
\text { isor } \\
\text { Dermaga. } \\
\text { TKBM men } \\
\text { gumpulkan } \\
\text { semua alat } \\
\text { bantu yang } \\
\text { dibutuhkan } \\
\text { dari gudang } \\
\text { dan } \\
\text { memasangn } \\
\text { ya pada } \\
\text { spreader } \\
\text { CC. } \\
\end{array}$ & \\
\hline 9 & $\begin{array}{l}\text { Pembongkara } \\
\text { n petikemas } \\
\text { dari kapal } \\
\text { ke atas truk }\end{array}$ & $\begin{array}{l}\text { Operator } \text { CC } \\
\text { membongkar } \\
\text { petikemas dari kapal } \\
\text { ke atas truk sesuai } \\
\text { arahan dari Petugas } \\
\text { Tally. }\end{array}$ & $\begin{array}{c}\text { Operator } \\
\text { CC, Petugas } \\
\text { Tally }\end{array}$ \\
\hline 10 & $\begin{array}{l}\text { Pemeriksaan } \\
\text { secara visual } \\
\text { kondisi fisik } \\
\text { dan nomor } \\
\text { petikemas }\end{array}$ & $\begin{array}{l}\text { Petugas Tally } \\
\text { Dermaga memeriksa } \\
\text { secara } \\
\text { visual kondisi fisik } \\
\text { dan nomor } \\
\text { petikemas. }\end{array}$ & $\begin{array}{l}\text { Petugas Tall } \\
\text { y Dermaga }\end{array}$ \\
\hline 11 & $\begin{array}{l}\text { Konfirmasi } \\
\text { dan } \\
\text { penginputan } \\
\text { hasil } \\
\text { pembongkara } \\
\text { n }\end{array}$ & \begin{tabular}{lr}
\multicolumn{2}{l}{ Petugas Tally } \\
Dermaga \\
mengkonfirmasi \\
hasil pembongkaran \\
di HHT & sesuai \\
dengan & nomor \\
petikemas yang \\
dibongkar & dan \\
menginputkan \\
nomor \\
petikemas.
\end{tabular} & $\begin{array}{l}\text { Petugas Tall } \\
\text { y Dermaga }\end{array}$ \\
\hline 12 & $\begin{array}{l}\text { Pengangkutan } \\
\text { petikemas dari } \\
\text { dermaga ke } \\
\text { lapangan } \\
\text { penumpukan }\end{array}$ & $\begin{array}{l}\text { Berdasarkan } \\
\text { instruksi yang } \\
\text { ditampilkan pada } \\
\text { VMT, pengemudi } \\
\text { truk mengangkut } \\
\text { petikemas dari } \\
\text { dermaga } \\
\text { lapangan } \\
\text { penumpukan. }\end{array}$ & $\begin{array}{l}\text { Pengemudi } \\
\text { truk }\end{array}$ \\
\hline
\end{tabular}

\begin{tabular}{|c|c|c|c|}
\hline Tahap & Aktivitas & Penjelasan & $\begin{array}{c}\text { Pihak Yang } \\
\text { Terlibat }\end{array}$ \\
\hline 13 & $\begin{array}{l}\text { Pemindahkan } \\
\text { petikemas dari } \\
\text { chassis head } \\
\text { truck ke } \\
\text { lokasi } \\
\text { penumpukan }\end{array}$ & $\begin{array}{l}\text { Operator RTG/RS } \\
\text { memindahkan } \\
\text { petikemas dari } \\
\text { chassis head } \\
\text { truck ke lokasi } \\
\text { penumpukan sesuai } \\
\text { dengan instruksi } \\
\text { yang ditampilkan } \\
\text { pada VMT. }\end{array}$ & $\begin{array}{l}\text { Operator } \\
\text { RTG/RS }\end{array}$ \\
\hline 14 & $\begin{array}{l}\text { Pemasangan } \\
\text { kabel reefer } \mathrm{d} \\
\text { an pengaturan } \\
\text { temperatur }\end{array}$ & $\begin{array}{lr}\text { Untuk } & \text { petikemas } \\
\text { reefer, } & \text { Personil } \\
\text { Pemantau } & \text { Reefer } \\
\text { memasang } & \text { kabel } \\
\text { reefer ke plug di } \\
\text { lapangan } \\
\text { penumpukan dan } \\
\text { mengecek } \\
\text { pengaturan } \\
\text { temperatur. }\end{array}$ & $\begin{array}{l}\text { Personil } \\
\text { Pemantau } \\
\text { Reefer }\end{array}$ \\
\hline 15 & $\begin{array}{l}\text { Penumpukan } \\
\text { petikemas di } \\
\text { lapangan } \\
\text { penumpukan }\end{array}$ & $\begin{array}{lr}\text { Petikemas yang } \\
\text { telah dibongkar } \\
\text { akan ditumpuk di } \\
\text { lapangan } \\
\text { penumpukan PT. } \\
\text { Terminal Petikemas } \\
\text { Surabaya untuk } \\
\text { dimuat kembali ke } \\
\text { kapal } \\
\text { dikeluarkan dari } \\
\text { terminal. }\end{array}$ & TPS \\
\hline
\end{tabular}

Sumber: Hasil pengolahan data, 2020

Sementara itu, SOP layanan pengeluaran petikemas di Terminal Petikemas Surabaya dimulai pengiriman delivery order online, pembuatan job order pengeluaran petikemas, pemrosesan job order pengeluaran petikemas, pemeriksaan data pada sistem, penyerahan job order kepada pengemudi truk, pengiriman urutan kerja pengeluaran petikemas, penyerahan job order oleh pengemudi, pemindaian kode job order, penginputan nomor polisi dan BAT, pencetakan dan penyerahan job slip, pengemudi menuju blok utama impor, pemindahan petikemas dari blok utama impor ke atas chassis truk, pencabutan kabel plug khusus petikemas reefer, konfirmasi pemindahan petikemas, pengembalian job slip, pengecekan antara data fisik dan sistem. Tabel berikut ini merupakan SOP layanan pengeluaran petikemas di Terminal Petikemas Surabaya.

Tabel 4. SOP Layanan Pengeluaran Petikemas Terminal Petikemas Surabaya

\begin{tabular}{|c|c|c|c|}
\hline Tahap & Aktivitas & Penjelasan & $\begin{array}{c}\text { Pihak Yang } \\
\text { Terlibat }\end{array}$ \\
\hline 1 & $\begin{array}{l}\text { Pengiriman } \\
\text { delivery order } \\
\text { online }\end{array}$ & $\begin{array}{lr}\text { Perusahaan } \\
\text { pelayaran } \\
\text { mengirimkan } \\
\text { file delivery order } \\
\text { online ke } & \text { PT. } \\
\text { Terminal Petikemas } \\
\text { Surabaya } \quad \text { untuk } \\
\text { setiap petikemas } \\
\text { yang } & \text { akan } \\
\text { dikeluarkan } & \text { dari } \\
\text { terminal. } & \\
\text { File delivery } & \text { order }\end{array}$ & $\begin{array}{c}\text { Perusahaan } \\
\text { pelayaran, } \\
\text { TPS }\end{array}$ \\
\hline
\end{tabular}




\begin{tabular}{|c|c|c|c|}
\hline Tahap & Aktivitas & Penjelasan & $\begin{array}{c}\text { Pihak Yang } \\
\text { Terlibat }\end{array}$ \\
\hline & & $\begin{array}{l}\text { online dapat } \\
\text { dikirimkan } \\
\text { menggunakan } \\
\text { format EDI atau } \\
\text { diunggah pada web } \\
\text { access PT. Terminal } \\
\text { Petikemas Surabaya }\end{array}$ & \\
\hline 2 & $\begin{array}{l}\text { Pembuatan } \\
\text { job order } \\
\text { pengeluaran } \\
\text { petikemas }\end{array}$ & $\begin{array}{l}\text { Pengguna jasa } \\
\text { dapat membuat job } \\
\text { order pengeluaran } \\
\text { petikemas dengan } \\
\text { aplikasi Clique } 247 . \\
\text { Data yang } \\
\text { diinputkan dan } \\
\text { sebagai berikut: } \\
\text { a. Nomor dan } \\
\text { tanggal } \\
\text { dokumen } \\
\text { persetujuan } \\
\text { Bea Cukai } \\
\text { bomor } \\
\text { delivery order } \\
\text { dari perusahaan } \\
\text { pelayaran dari } \\
\text { c. PIN perusahaan } \\
\text { pelayaran }\end{array}$ & $\begin{array}{l}\text { Pengguna } \\
\text { jasa }\end{array}$ \\
\hline 3 & $\begin{array}{l}\text { Pemrosesan } \\
\text { job order } \\
\text { pengeluaran } \\
\text { petikemas }\end{array}$ & $\begin{array}{l}\text { Setelah semua data } \\
\text { job order diinput, } \\
\text { maka aplikasi Clique } \\
247 \text { akan memproses } \\
\text { data yang diinputkan } \\
\text { oleh pengguna jasa. }\end{array}$ & TPS \\
\hline 4 & $\begin{array}{l}\text { Pemeriksaan } \\
\text { data pada } \\
\text { sistem }\end{array}$ & $\begin{array}{l}\text { Pengguna jasa wajib } \\
\text { mengecek data } \\
\text { petikemas yang } \\
\text { ditampilkan oleh } \\
\text { sistem. } \\
\text { a. Apabila } \\
\text { terjadi ketidaks } \\
\text { esuaian data } \\
\text { petikemas, } \\
\text { pengguna jasa } \\
\text { wajib } \\
\text { mengklarifikas } \\
\text { i kepada } \\
\text { perusahaan } \\
\text { pelayaran. } \\
\text { Kemudian, } \\
\text { perusahaan } \\
\text { pelayaran } \\
\text { mengirimkan } \\
\text { kembali data } \\
\text { delivery order } \\
\text { online jika } \\
\text { menerima } \\
\text { informasi dari } \\
\text { pengguna jasa. } \\
\text { Apabila data } \\
\text { petikemas } \\
\text { telah sesuai, } \\
\text { pengguna jasa } \\
\text { dapat } \\
\text { melanjutkan }\end{array}$ & $\begin{array}{l}\text { Pengguna } \\
\text { jasa, } \\
\text { Perusahaan } \\
\text { pelayaran }\end{array}$ \\
\hline
\end{tabular}

\begin{tabular}{|c|c|c|c|}
\hline Tahap & Aktivitas & Penjelasan & $\begin{array}{c}\text { Pihak Yang } \\
\text { Terlibat }\end{array}$ \\
\hline & & $\begin{array}{l}\text { pembuatan job } \\
\text { order dan } \\
\text { mencetaknya. }\end{array}$ & \\
\hline 5 & $\begin{array}{l}\text { Penyerahan } \\
\text { job order } \\
\text { kepada } \\
\text { pengemudi } \\
\text { truk }\end{array}$ & \begin{tabular}{lr}
\multicolumn{2}{l}{ Pengguna jasa } \\
mendistribusikan \\
job order yang telah \\
dicetak kepada \\
pengemudi truk \\
sebelum masuk \\
ke dalam terminal.
\end{tabular} & $\begin{array}{l}\text { Pengguna } \\
\text { jasa, } \\
\text { Pengemudi } \\
\text { truk }\end{array}$ \\
\hline 6 & $\begin{array}{l}\text { Pengiriman } \\
\text { urutan kerja } \\
\text { pengeluaran } \\
\text { petikemas }\end{array}$ & $\begin{array}{l}\text { Sambil menunggu } \\
\text { kedatangan } \\
\text { pengemudi truk, } \\
\text { Yard Dispatcher } \\
\text { mengirimkan urutan } \\
\text { kerja pengeluaran } \\
\text { petikemas. }\end{array}$ & $\begin{array}{c}\text { Yard } \\
\text { Dispatcher }\end{array}$ \\
\hline 7 & $\begin{array}{l}\text { Penyerahan } \\
\text { job order ole } \\
\text { h pengemudi }\end{array}$ & $\begin{array}{l}\text { Pengemudi truk } \\
\text { yang telah memiliki } \\
\text { job order menuju ke } \\
\text { gate-in dan } \\
\text { menyerahkan job } \\
\text { order kepada } \\
\text { Personil Gate-In. }\end{array}$ & $\begin{array}{l}\text { Pengemudi } \\
\text { truk, } \\
\text { Personil } \\
\text { Gate-In }\end{array}$ \\
\hline 8 & $\begin{array}{l}\text { Pemindaian } \\
\text { kode job } \\
\text { order }\end{array}$ & $\begin{array}{l}\text { Personil Gate- } \\
\text { In memindai kode } \\
\text { batang job order. }\end{array}$ & $\begin{array}{l}\text { Personil Gat } \\
\quad e-I n\end{array}$ \\
\hline 9 & $\begin{array}{l}\text { Penginputan } \\
\text { nomor Polisi } \\
\text { dan BAT }\end{array}$ & $\begin{array}{l}\text { Personil Gate- } \\
\text { In menginput nomor } \\
\text { polisi dan nomor } \\
\text { BAT. }\end{array}$ & $\begin{array}{l}\text { Personil Gat } \\
\quad \text { e-In }\end{array}$ \\
\hline 10 & $\begin{array}{l}\text { Pencetakan } \\
\text { dan } \\
\text { penyerahan } \\
\text { job slip }\end{array}$ & $\begin{array}{l}\text { Personil Gate-In } \\
\text { mencetak job slip } \\
\text { untuk pengemudi } \\
\text { truk dan } \\
\text { menyerahkannya } \\
\text { kepada pengemudi } \\
\text { truk. }\end{array}$ & $\begin{array}{c}\text { Personil Gat } \\
\text { e-In, } \\
\text { Pengemudi } \\
\text { truk }\end{array}$ \\
\hline 11 & $\begin{array}{l}\text { Pengemudi } \\
\text { menuju blok } \\
\text { utama impor }\end{array}$ & $\begin{array}{l}\text { Pengemudi truk } \\
\text { yang telah memiliki } \\
\text { job slip menuju ke } \\
\text { blok utama impor } \\
\text { sesuai yang tertera di } \\
\text { dalam job slip. }\end{array}$ & $\begin{array}{l}\text { Pengemudi } \\
\text { truk }\end{array}$ \\
\hline 12 & $\begin{array}{l}\text { Pemindahan } \\
\text { petikemas } \\
\text { dari blok } \\
\text { utama impor } \\
\text { ke atas } \\
\text { chassis truk }\end{array}$ & $\begin{array}{l}\text { Operator RTG/RS } \\
\text { memindahkan } \\
\text { petikemas dari blok } \\
\text { utama impor ke atas } \\
\text { chassis truk dan } \\
\text { mengkonfirmasinya } \\
\text { melalui VMT. }\end{array}$ & $\begin{array}{l}\text { Operator } \\
\text { RTG/RS }\end{array}$ \\
\hline 13 & $\begin{array}{l}\text { Pencabutan } \\
\text { kabel plug } \\
\text { khusus } \\
\text { petikemas } \\
\text { reefer }\end{array}$ & $\begin{array}{l}\text { Untuk petikemas } \\
\text { reefer, Personil } \\
\text { Pemantau Reefer } \\
\text { mencabut kabel plug } \\
\text { sebelum petikemas } \\
\text { dipindahkan. }\end{array}$ & $\begin{array}{c}\text { Personil } \\
\text { Pemantau } \\
\text { Reefer }\end{array}$ \\
\hline 14 & $\begin{array}{l}\text { Konfirmasi } \\
\text { pemindahan } \\
\text { petikemas }\end{array}$ & $\begin{array}{l}\text { Setelah melakukan } \\
\text { pemindahan } \\
\text { petikemas ke atas } \\
\text { chassis rruk, } \\
\text { Operator RTG/RS } \\
\text { melakukan } \\
\text { konfirmasi melalui } \\
\text { VMT. }\end{array}$ & $\begin{array}{l}\text { Operator } \\
\text { RTG/RS, } \\
\text { Pengemudi } \\
\text { truk }\end{array}$ \\
\hline
\end{tabular}




\begin{tabular}{|c|c|c|c|}
\hline Tahap & Aktivitas & Penjelasan & $\begin{array}{c}\text { Pihak Yang } \\
\text { Terlibat }\end{array}$ \\
\hline 15 & $\begin{array}{l}\text { Pengembalian } \\
\text { job slip }\end{array}$ & $\begin{array}{l}\text { Pengemudi truk } \\
\text { menuju ke gate- } \\
\text { out dan } \\
\text { mengembalikan job } \\
\text { slip kepada Personil } \\
\text { Gate-Out. }\end{array}$ & $\begin{array}{l}\text { Pengemudi } \\
\text { truk, } \\
\text { Personil Gat } \\
\text { e-Out }\end{array}$ \\
\hline 16 & \begin{tabular}{ll}
\multicolumn{2}{l}{ Pengecekan } \\
antara data \\
fisik dan \\
sistem
\end{tabular} & $\begin{array}{l}\text { Personil Gate-Out } \\
\text { mengecek apakah } \\
\text { data fisik petikemas } \\
\text { dengan data di dalam } \\
\text { sistem telah sesuai. } \\
\text { Apabila data fisik } \\
\text { petikemas dan data } \\
\text { di dalam sistem telah } \\
\text { sesuai, Personil } \\
\text { Gate-Out } \\
\text { mengkonfirmasikan } \\
\text { bahwa proses telah } \\
\text { selesai. }\end{array}$ & $\begin{array}{l}\text { Personil } \\
\text { Gate-Out }\end{array}$ \\
\hline
\end{tabular}

Sumber: Hasil pengolahan data, 2020

\section{KESIMPULAN}

Berdasarkan hasil analisis, maka dapat ditarik kesimpulan bahwa SOP layanan penerimaan petikemas dimulai dari pengiriman data COPARN, pembuatan job order, pencetakan dan distribusi E-CEIR, proses pemindahan petikemas dari truk ke lapangan penumpukan, hingga kendaraan meninggalkan terminal. Sementara itu, SOP layanan pemuatan petikemas dimulai dari pengiriman, penerimaan dan pemeriksaan dokumen, pemindahan petikemas dari lapangan penumpukan ke truk untuk dimuat ke kapal, hingga konfirmasi muatan dan keberangkatan kapal. Untuk SOP layanan pembongkaran petikemas dimulai dari persiapan pembongkaran, menginput data ke dalam sistem, pembongkaran petikemas dari kapal ke atas truk, pemeriksaan, mengangkut petikemas dari dermaga ke lapangan penumpukan, hingga pemindahkan petikemas dari truk ke lapangan penumpukan. Sedangkan, SOP layanan pengeluaran petikemas dimulai pengiriman delivery order online, pembuatan job order pengeluaran petikemas, pemrosesan job order pengeluaran petikemas, hingga pengecekan antara data fisik dan sistem.

Saran untuk perusahaan diharapkan melakukan sosialisasi kepada para pengguna terminal sehingga diharapkan tidak ada pengguna terminal salah dalam melakukan tahapan aktivitas baik dalam hal layanan pemasukan, pemuatan, pembongkaran, ataupun pengeluaran petikemas. Perusahaan juga diharapkan membuat SOP yang mudah dipahami oleh pengguna terminal. Sedangkan untuk peneliti selanjutnya diharapkan menggunakan metode yang dapat mengidentifikasi pemahaman para pengguna terminal terhadap SOP yang ada, dan melihat dampak dari SOP yang ada terhadap kinerja baik dari sisi efisiensi atau efektivitas dalam aktivitas pemasukan, pemuatan, pembongkaran, ataupun pengeluaran petikemas. Selain itu juga dapat menggali permasalahan dalam implementasi SOP yang ada dan kondisi terminal saat sehingga nantinya dapat dijadikan bahan untuk pengambilan kebijakan perusahaan dalam rangka untuk meningkatkan kepuasan pengguna terminal petikemas Surabaya (TPS).

\section{REFERENSI}

Jurnal:

[1] Amanullah, L. H., Mardika, M. G. I., Hargono, S., \& Salamun. (2018). Kajian Layanan Dan Utilitas Dermaga Terminal Peti Kemas Pelabuhan Panjang. Jurnal Karya Teknik Sipil, 7(1), 109-120.

[2] Gabriele. (2018). Analisis Penerapan Standar Operasional Prosedur (SOP) Di Departemen Marketing dan HRD PT. Cahaya Indo Persada. Jurnal AGORA, 6(1), 1-10.

[3] Handajani, M. (2004). Analisis Kinerja Operasional Bongkar Muat Peti Kemas Pelabuhan Tanjung Emas Semarang. Jurnal Transportasi, 4(1), 1-12.

[4] Khusyairi, A., \& Hisyam, E. S. (2016). Analisis Kinerja Pelayanan Operasional Peti Kemas di Pelabuhan Pangkalbalam Kota Pangkalpinang. Jurnal Fropil, 4(2), 74-86.

[5] Rachmi, A., Susanto, T. D., \& Herdiyanti, A. (2014). Pembuatan Standard Operating Procedure (SOP) Service Desk Berdasarkan Kerangka Kerja ITIL V3 dengan Menggunakan Metode Analisis Gap Layanan ( Studi Kasus : PT XZY Tangerang). Jurnal Teknik Pomits, 3(2), 175-180.

[6] Somadi, \& Hidayat, F. (2019). Rancangan Strategi Untuk Mengatasi Penolakan Truk Dan Kontainer Oleh Customer. Jurnal Logistik Bisnis, 09(2), 118124.

[7] Wahono, D. (2015). Terminal Petikemas pada Pelabuhan Internasional Pantai Kijing di Kecamatan Sungai Kunyit Kabupaten Pontianak. Jurnal Online Mahasiswa Arsitektur Universitas Tanjungpura, 3(1), 37-55.

\section{Thesis/Disertation:}

[8] Bastyan, E. (2017). Analisa Kualitas Layanan Bongkar Muat Di Terminal Petikemas Surabaya Dengan Metode SERVQUAL Dan QFD. Manajemen Teknologi Bidang Keahlian Manajemen Proyek Fakultas Bisnis dan Manajemen Teknologi Institut Teknologi Sepuluh Nopember.

\section{Textbooks:}

[9] Budihardjo, M. (2014). Panduan Praktis Menyusun SOP . Jakarta: Raih Asa Sukses.

[10] Santosa, J. K. ( 2014). Lebih Memahami SOP. Surabaya: Kata Pena.

[11] Tathagati, A. (2014). Step by step membuat SOP. Jakarta: Efata Publishing. 